\title{
Verbal and Non-Verbal Signs of "Moana Movie Poster
}

\author{
Putu Andhika Dhananjaya \\ ${ }^{[123]}$ English Department - Faculty of Arts - Udayana University \\ [dhikadhananjaya@gmail.com] \\ *Corresponding Author
}

\begin{abstract}
The study is entitled Verbal and Non-Verbal Signs of "Moana" Movie Posters. This study focused on the analysis of verbal and non-verbal signs of "Moana" movie poster and the meaning of those signs. It was aimed at identifying the verbal and non-verbal signs found in "Moana" movie posters. It was also aimed at explaining the meaning of verbal and non-verbal signs in those movie posters. The data of this study were taken from the websites namely www.impawards.com. The data were collected using the documentation method. Then, the collected data were qualitatively and descriptively analyzed based on the theories applied in this study, namely the theories of semiotics proposed by Saussure, theory of verbal and non-verbal signs proposed by Dyer, and supported with the theory of color terms proposed by Wierzbicka, and theory of color meaning proposed by Eisman. The result of analysis shows that "Moana" movie posters have verbal and non-verbal signs. The verbal signs are "Disney", "Moana", "Sing with Moana!", "Sing-Along", "Special Sing-Along Engagement", "January $27^{\text {th }}$ in Select Theatres Nationwide", "Soundtrack Available Now", "From the Creators of Zootopia and Frozen", "November 23", "In 3D and Real D 3D", "The Ocean is Calling", Dwayne Johnson as Maui", and "Auli'i Cravalho as Moana". Those verbal signs provide the information about the title, release date, movie quality, the information of actor and actress as voices over, the information about the soundtrack of the movie, as well as company and creator that produced the movie. Then, the nonverbal signs consist of shape, appearance, manner activity, background, and color.
\end{abstract}

Keywords: Verbal Sign, Non-Verbal Sign, Movie Poster.

\begin{abstract}
Abstrak
Judul penelitian ini adalah Verbal and Non-Verbal Signs of "Moana" Movie Posters. Penelitian ini difokuskan pada analisis tanda-tanda verbal dan non-verbal dari posterposter film "Moana", dan makna dari tanda-tanda tersebut. Penelitian ini bertujuan untuk mengidentifikasi tanda-tanda verbal dan non-verbal yang ditemukan pada posterposter film "Moana". Penelitian ini juga bertujuan untuk menjelaskan makna dari tanda-tanda verbal dan non-verbal di dalam poster-poster film tersebut. Data dari penelitian ini diambil dari websites yang bernama www.impawards.com. Data tersebut dikumpulkan dengan menggunakan metode dokumentasi. Kemudian, data yang dikumpulkan secara kualitatif dan deskriftif dianalisis berdasarkan teori-teori yang diterapkan pada penelitian ini, yaitu teori-teori semiotics yang dikemukakan oleh Saussure, teori tanda-tanda verbal dan non-verbal yang dikemukakan oleh Dyer, dan didikung dengan teori tentang istilah-istilah warna yang dikemukakan oleh Wierzbicka, dan teori mengenai makna warna yang dikemukakan oleh Eisman. Hasil dari analisis
\end{abstract}


menunjukkan bahwa poster-poster film "Moana" memiliki tanda-tanda verbal dan nonverbal. Tanda-tanda verbal tersebut adalah "Disney", "Moana", "Sing with Moana!", "Sing Along", "Special Sing Along-Engagement", "January $27^{\text {th }}$ in Select Theatres Nationwide", "Soundtrack Available Now", "From the Creators of Zootopia and Frozen", "Novemeber 23", "In 3D and Real D 3D", "The Ocean is Calling", "Dwayne Johnson as Maui", "Auli'i Cravalho as Moana”. Tanda-tanda verbal tersebut menyediakan informasi tentang judul, tanggal perilisan, kualitas film, informasi tentang aktor dan artis sebagai pengisi suara, informasi tentang soundtrack dari film tersebut, serta perusahan dan pembuat film tersebut. Kemudian, tanda-tanda non-verbal terdiri dari bentuk, penampilan, gaya, aktivitas, latar belakang, dan warna.

\section{Kata kunci: Tanda Verbal, Tanda Non-Verbal, Poster Film.}

\section{Background of the Study}

Signs can be found in many aspects of life that represent certain concept or meaning. Sign is not limited only to alphabet, but also includes symbol and picture. The study about sign and its meaning is known as Semiotics. Saussure (as cited in Chandler, 2001) defines semiotics as the science of signs in society. Semiotics focuses on something that can be considered as a sign. The sign can also be divided into verbal and non-verbal sign. Verbal sign involves words while non-verbal sign includes pictures. Therefore, sign covers a wide scope of category ranging from a simple sign (symbol to a more complicated such as pictures and colors).

The application of verbal and nonverbal signs is also found in movie poster. Movie poster has a lot of signs, namely verbal and non-verbal signs, meanings, as well as messages it delivers. The verbal signs in movie poster are the texts presented in movie poster, and then the non-verbal in movie poster includes pictures and colors. There are many kinds of movie poster and one of them is Moana movie poster.

"Moana", a western movie, is one of an adventure movie, the story tells about a spirited teenager who sails out on a daring mission to prove herself a master way finder and fulfill her ancestors' unfinished quest. It posters consists of interesting pictures animation and texts, which have the verbal and non-verbal signs that require to be analyzed.

Thus, this study focused on analyzing what verbal and non-verbal signs were used in the posters and the meaning of those signs. By analyzing the movie posters, it is expected that it can help people understand the meanings or messages of the signs in the movie posters appropriately. In addition, it helps avoid people's misunderstanding on those signs.

\section{Problem of the Study}

a. How verbal and non-verbal signs are presented in "Moana" movie posters?

b. What are the meanings of those verbal and non-verbal signs?

\section{Aims of the Study}

a. To identify the verbal and non-verbal signs presentation in the "Moana" movie posters.

b. To explain the meanings of those verbal and non-verbal signs in the "Moana" movie posters.

\section{Research Method}

The research method in this study consists of data source, method and technique of collecting data, and method and technique of analyzing data. 


\subsection{Data Source}

The data used in this study were taken from some websites. The Moana movie posters were downloaded from www.impawards.com. In this website, there were fourteen posters of "Moana" with the unique design, awesome picture, nice color, good words or sentence. In addition, there were three selections of Moana movie posters for this study, namely the movie posters chosen based on the compositions of verbal and nonverbal signs. The selected movie posters also use the persuasive language to attract the attention of the readers. The Moana movie tells about a spirited teenager who sails out on a daring mission to prove herself a master way finder and fulfill her ancestors' unfinished quest. Moana (/mov'a:nə/) is a 2016 American computer-animated musical fantasy-adventure film produced by Walt Disney Animation Studios and released by Walt Disney Pictures. It is the 56th Disney animated feature film.

\subsection{Method and Technique of Collecting Data}

The method used in collecting the data was the documentation method. The "Moana" movie posters were selected because they provide enough data related to the problems to be analyzed. There are sixth techniques in collecting the data. Firstly, visiting some websites; secondly, determining the selected websites; thirdly, choosing the movie posters; fourthly, downloading the movie posters of Moana from the websites from internet; fifthly, identifying the verbal and non-verbal signs found in those movie posters. And the last, observing the meanings of verbal and non-verbal signs in those movie posters.

\subsection{Method and Technique of Analyzing Data}

The verbal and non-verbal signs presented in those posters were analyzed. In analyzing the data, descriptive qualitative method was applied. The first step of the data analysis was identifying the data collected whether they belong to verbal or non-verbal signs. The collected data were analyzed through several steps. First, the theory proposed by Dyer (1993) about verbal and non-verbal was used to identify the verbal and non-verbal signs in the "Moana" movie posters. Then, the theory of signifier and signified proposed by Saussure (1983), and the theory of color terms proposed by Wierzbicka (1996), and also theory of color meaning proposed by Eiseman (2000) were used to find out the meanings of verbal and non-verbal signs in the those movie posters.

\subsection{Method and Technique of Presenting Data \\ The presentation of result of analysis} in this study used formal technique. The technique was used as result of analysis was in the form of description using sentences. The description was focused on the identification of the verbal and non-verbal signs found in "Moana" movie posters, and explanation of the meaning of verbal and non-verbal signs in those movie posters.

\section{Analysis}

\subsection{Analysis of Verbal and Non-Verbal} Signs of "Moana" Movie Posters, and Their Meaning

This part consists of the analysis of the data beginning with the identification of the verbal and nonverbal signs presentation in the "Moana" movie posters, and the meanings of those signs were found out. 


\subsubsection{Verbal Signs}

a. On the top of first poster, there is verbal sign "DWAYNE JOHNSON AS MAUI". It placed on the top left part of this poster, written in capital letters with dark blue color.

b. The second verbal sign in the first poster is the words "AULI'I CRAVALHO AS MOANA". It placed on the top right part of this poster, written in capital letters with dark blue color.

c. The next verbal sign is the word "MOANA". It is the main text in the three posters, it is placed on the bottom middle part of those poster, written in capital letters with white color.

d. The first verbal sign in poster three, there is a slogan "THE OCEAN IS CALLING". It is placed on the middle right part of third poster, written in capital letters with dark blue color.

\subsubsection{Non-Verbal Signs \\ a. Shape}

Shape in poster one is represented in the form of crack ocean, green hill, blue sky. Shape in poster two is represented in form of characthers, such as: girl, man, pig, and rooster. And non-verbal signs in poster three is represented in form of ocean, clear sky, sailboat, and human body.

\section{b. Apperance}

In the first poster, there are many fish and a turtles swimming inside the water of the ocean. There are also a man, a young girl, a pig, and a cock obviously seen in the picture. A man has a big body, dark skin, curly hair. He is wearing leaf cloth a necklace made of bone on his neck. His body is full of tattoos. He is also bringing a hook as his weapon. A slim young girl with brown skin, curly brown hair is wearing a red cloth and white skirt, necklace is standing up beside the man. She is holding an oar. A white pig with pink nose is sitting beside the girl. A cock with big eyes, red com, yellow and green fur, and yellow foot are standing on the pig.

\section{c. Manner}

The main character named "Moana" looks like a spirit teenager girl. She is standing gently while holding the oar firmly. In addition, she is also smiling beautifully. Her eyes are looking forward smilingly and friendly. The man named Maui has a well-built body. $\mathrm{He}$ is standing up gently and looking forward firmly. He is hugging a weapon tightly. His gaze with big eyes looks as if he was looking at things seriously. His tattoo makes him look angry. The pig is sitting down carefully beside Moana. The cock is standing up on the head of the pig. The turtles and fish are swimming inside the water.

\section{d. Activity}

In the first poster, there is teenage girl named Moana. She is standing on the sand in the middle of the wave of the ocean. She is smiling, and bringing an oar on the back of her shoulder. And then there is a big guy with full of tattoos on his body, his name is Maui. $\mathrm{He}$ is standing on the sand in the middle of the ocean. He is smiling a bit and looking forward firmly while hugging a big hook as his weapon. There is a pig sitting down beside Moana and a cock standing on the head of the pig. There are some other animals like the fish and turtles swim inside the water of the ocean.

\section{e. Background}

The background of three posters are the blue ocean with the blue sky and much of clouds.

\section{f. Color}

a. The blue color is used as the color of the sky and the water of the ocean. 
b. The dark blue color is used as the color of the verbal signs "DWAYNE JOHNSON AS MAUI", "AULI'I CRAVALHO AS MOANA", and "FROM CREATORS OF ZOOTOPIA AND FROZEN".

c. The black color is used as the color of the tattoos of the big guy (Maui), the eyebrow of the big guy (Maui), the eyebrow of the girl (Moana), the eyeball of Maui, Moana, cock, and the pig.

d. The dark brown color is used as the color of the big guy (Maui's) hair, the girl (Moana's) hair, color of the Maui's skin, Moana's skin, color of oar, color of the rope used to tie the hook handle.

e. The green color is used as the color of the plants of the hill, the leaves of the coconut trees, the leaves are used as the clothes of Maui, the fish, and turtle.

f. The white color is used as the color of the texts such as "Disney", "MOANA", "NOVEMBER 23", IN 3D AND REALD 3D". And the color white is also as the color of Moana's skirt, the hook, the necklace of Maui, and the color of feathers from pig.

g. The red color is used as the color of Moana's clothes, Moana's belt, and the color of rooster's cock.

h. The brown color is used as the color of the sand, and the color of the rock.

i. The yellow color is used as the color of the foot of the cock, and the color of the feathers from the rooster's neck.

j. The pink color is used as the color of the pig's nose, and inside the ear of the pig.

\subsection{Explanation of the Meanings of Verbal and Non-Verbal Signs in "Moana" Movie Posters}

In this section, the analysis is presented in three parts; they are first, analysis the meaning of verbal signs in those movie posters, analysis of the meaning of non-verbal signs in those movie posters, and analysis of color meaning.

\subsubsection{The Meaning of Verbal Signs}

There are eighteen verbal signs found in the three movie posters. Those verbal signs have meanings and messages as follows:

\section{a. DWAYNE JOHNSON AS MAUI}

This signifier signifies that Dwayne Johnson acts as Maui in the movie.

\section{b. AULI'I CRAVALHO AS MOANA}

This signifier signifies that Auli'i Cravalho acts as Moana in the movie.

\section{c. Moana}

This signifier signifies the title of the movie.

\section{d. THE OCEAN IS CALLING}

This slogan signifies that Mona feels something in herself and has a faith that ocean has called her to sail to the open ocean to do a mission to meet Maui.

\subsubsection{The Meaning of Non-Verbal Signs}

\section{a. Analysis of Poster 1}

From the first poster, it can be obviously seen that the wave is cracked into two parts and curls. Behind the wave is a rocky hill as its background. The hill is full of green plants one of which is a group of coconut trees. Inside the reef curl, there is a turtle and various fish swimming gently. Inside the wave crack, there is a girl standing on the sand. She stands in front of the others. There is also a pig sitting beside the girl. On the head of the pig the rooster is standing gently. A part from those characters, there is a man with a big body standing behind the girl. The man stands firmly with tattoofull body. This is evidence that the poster intends to show the main character of the film. 


\section{b. Analysis of Poster 2}

The second poster tells us about a voyage in the sea. It can clearly be seen that this is a sunny day as the sky looks bright and the ocean looks blue. The ocean looks wild as the wave is big and strong. It seems that it is in an open sea. It is also windy as the wave and current look strong. There is a boat on the voyage. The boat is carrying four characters, Moana, Maui, the pig and the rooster. It is a simple boat made of wood. It only uses screen to help it run as it doesn't use motor or any machine. The situation tells us that the boat sails long distance.

\section{c. Ananlysis of Poster 3}

On the third poster, the setting is in the blue ocean under the sunny blue sky. From distance, there are two people sailing on a boat. The boat sails fast. It is a sunny, bright day. The wave looks big, and the current is strong as it is windy. The boat seems to sail to an island. Readers can only see two characters (Moana and Maui) from back side. Readers are not able to see what their face look like. They are not able to search for Moana's face and her specific features. They are also unable to see Maui face as it is distance.

When the readers see the poster, they will get confused and want to know who Moana is and why she is on a voyage to an island with the big man. Readers will be curious about the complete story of the film. In addition, as the sail of the booth they ride contains a symbol derived from a letter found in the name "Moana", readers will wonder what it means and why it looks so. Moreover, a writing "THE OCEAN IS CALLING" will be a puzzle to know meaning behind it that the readers have to watch the whole story of the film.

\subsubsection{Analysis of Color Terms \\ a. Blue}

Blue color is used in the three posters. The color is used as that of ocean and sky. The color is frequently associated with sky and ocean as it is natural color of the two things. Blue symbolizes peace, quite, health, recovery as well as refreshing. It is also frequently associated with depth and stability. People also associate blue color with the biggest water source, such as ocean or lake. The color certainly gives a sense of peace and patience. Readers who see it will feel peaceful.

\section{b. Green}

'In the first poster, green is used as that of plantations grown on the hill, such as coconut leaf, the fish and the turtle. It is the color of the nature. It is symbol of growth, harmony, freshness, and fertility. It implies that there is harmony in the hill and in the sea. Some words associated with green color are patience, patience, making thing patient or cooling down, fresh, making thing fresh, traditional, stable, ambition, conservation, calm, wide, and relaxed.

\section{c. Brown}

Brown is used in the three posters. In the first poster, brown is used as the color of sand, an oar held by the girl (Moana) on her shoulder, as well as the color of rope used to tie the big hook held by the big man (Maui).

\section{d. White}

White is used in the three posters. Many verbal signs in the first, second, and third poster use white. White is usually associated with light, truth, purity, and virginity. The color is often considered the symbol of perfectness. White also represents safety, purity, and cleanness.

\section{e. Red}

Red is frequently known as a warm color as it is related to fire. Some words 
are often related to red color, such as strength, power, happiness, sexuality, sensitiveness. In each poster, red is used as the color of the girl (Moana), that is, the color of her shirt and her waist sash. The red color signalizes that the poster designer wants to present that the girl is someone who has power and happiness.

\section{f. Black}

Black is used in all posters. Black is used as the color of eyebrow and eyeball of the girl (Moana) and the big man (Maui). It is also used for the color of cock's and pig's eyeball. It may indicate that the poster designer wants to use a natural color used in human body part, such as human's eyebrow and eyeball, in the real life situation.

\section{g. Purple}

Purple in the poster is used as the color of rock in the hill, particularly found in the first poster. The color is used as natural color of rock in the real life. It signalizes that the poster designer wants to present something found in the real life condition.

\section{h. Yellow}

Yellow is the color of warmness as it is related to the sun. It is also frequently related to warning, damage, diseases, and alertness. The color is used slightly, particularly in the first poster and second poster only. Yellow in the first poster is used as the color of feet and neck feather of cock. The designer uses yellow color to make the cock looks cuter.

\section{i. Pink}

Pink is usually related to feminism and weakness. Pink also signalizes a woman and things related to a woman. Sensitivity is also signalized with pink. In addition, it is used to be a sign of romance, love, as well as partnership. In the first and second posters specially, pink is used for that of inside part of ear and nose of the pig. The color is used by the designer to make the pig look cuter and interesting.

\section{Conclusion}

Based on the analysis and discussion, there are two main conclusions that can be drawn; they are the presence and the meaning of verbal and non-verbal signs. Verbal signs in the three posters are presented in the form of writing. Poster one represents seven verbal signs, they are: "DWAYNE JOHNSON AS MAUI", "AULI'I CRAVALHO AS MOANA", "FROM CREATORS OF ZOOTOPIA \& FROZEN", "Disney", "MOANA", "NOVEMBER 23", "IN 3D AND REALD 3D". In poster two, there are seven verbal signs found; they are: "SING WITH MOANA!", "Disney", "MOANA", "SING-ALONG", "SPECIAL "SING-ALONG ENGAGEMENT", "JANUARY $27^{\mathrm{TH}}$ IN SELECT THEATRES NATIONWIDE", and "SOUNDTRACK AVAILABLE NOW". However, poster three consists of only four verbal signs; they are: "THE OCEAN IS CALLING", "Disney", "MOANA", and "NOVEMBER 23".

The non-verbal signs found in the three posters vary, including shape, appearance, manner, activity, background, and color. For example, shape in poster one is represented in the form of crack ocean, green hill, blue sky. Shape in poster two is represented in form of characthers, such as: girl, man, pig, and rooster. And non-verbal signs in poster three are represented in the forms of ocean, clear sky, sailboat, and human body.

The meanings of those signs are devided into two parts: verbal sign meaning and non-verbal sign meaning. There are eighteen verbal signs found in the three movie posters each of which has own meaning. "DWAYNE 
JOHNSON AS MAUI" means that Dwayne Johnson is the real name and Maui is the name of the man character. "AULI'I CRAVALHO AS MOANA" means that Auli'i Cravalho is the real name and Moana is the name of the girl character. "Moana" means that the title of the movie as well as the name of the girl character. "THE OCEAN IS CALLING" means that the slogan of this movie and signifies that Moana feels something in herself and has faith that the ocean called her to sail to open ocean to make a mission meet Maui. Nonverbal signs are signalized by the presence of various colors. Those colors are blue, green, brown, white, red, balck, purple, yellow, and pink, which symbolize peace, freshness, warmth, purity, power, formality, naturalness, warning, romance respectively.

\section{Reference}

Chandler, Daniel. 2001. Semiotics for Beginners:http://visualmemory.co.u $\mathrm{k} /$ daniel /Documents/S4B/ (accessed on May 3, 2017).

Dyer, Gillian. 1986. Advertising as Communication. London: Methuen \& Co. Ltd.

Dyer, Gillian. 1993. Advertising as Communication.London:

Routledge.

Eisman, Leatrice. 2000. Colors for Everyday Mood. Capital Book Inc: Virginia.

Wierzbicka,

Anna. 1996.

Semantics:Primes and Universals. Oxford University Press

http://www.impawards.com/2016/moana. html. (accessed on May 3, 2017). http://www.impawards.com/2016/moana _ver4.html. (accessed on May 3, 2017).

http://www.impawards.com/2016/moana _verl4.html. (accessed on May 3, 2017). 